\title{
Coping strategies in individuals at risk and not at risk of mobile phone addiction
}

\author{
Sposoby radzenia sobie ze stresem u osób zagrożonych \\ i niezagrożonych uzależnieniem od telefonu komórkowego
}

\section{Ewa Dziurzyńska ${ }^{1}$ A,B,D,E,F,G, Beata Pawłowska ${ }^{2}$ A,E,G, Emilia Potembska ${ }^{3}$ C,E,F}

\author{
${ }^{1}$ Department of Psychology of the University of Rzeszów \\ $22^{\text {nd }}$ Department of Psychiatry and Psychiatric Rehabilitation, Medical University of Lublin \\ ${ }^{3}$ Department of Psychiatric Nursing, Medical University of Lublin
}

\begin{abstract}
The aim of the present study was to provide an answer to the question of whether, and what, differences in stress coping strategies could be found between university students at risk and those not at risk of mobile phone addiction. The study included 408 students aged 19 to 28 years. The following instruments were used: a sociodemographic questionnaire, the Mobile Phone Addiction Assessment Questionnaire (in Polish, Kwestionariusz do Badania Uzależnienia od Telefonu Komórkowego, KBUTK) by Pawłowska and Potembska, and the Coping with Stress Questionnaire (SVF) by Janke, Erdmann, and Boucsein, translated into Polish by Januszewska. The results of the study showed that individuals at risk of mobile phone addiction were more likely to cope with stress by seeking substitute gratification, reacting with resignation, passivity, dejection and hopelessness, blaming themselves, pitying themselves and looking for support. They also tended to ruminate over their suffering, withdraw from social interactions, react with aggression and/or take to drinking.
\end{abstract}

Keywords: mobile phone addiction, coping with stress

\section{Streszczenie}

Celem badania było udzielenie odpowiedzi na pytanie: czy i jakie różnice występują w zakresie sposobów radzenia sobie ze stresem między studentami zagrożonymi i niezagrożonymi uzależnieniem od telefonu komórkowego? W badaniu uczestniczyło 408 studentów szkół wyższych, w wieku 19 - 28 lat. Wykorzystano następujące narzędzia badawcze: Ankietę socjodemograficzną, Kwestionariusz do Badania Uzależnienia od Telefonu Komórkowego (KBUTK), autorstwa B. Pawłowskiej i E. Potembskiej, Kwestionariusz Radzenia Sobie ze Stresem (KRS), autorstwa W. Janke, G. Erdmann, W. Boucsein, w polskim tłumaczeniu E. Januszewskiej. Wyniki badań wskazują, że osoby zagrożone uzależnieniem od telefonu komórkowego w porównaniu z grupą kontrolną znacząco częściej w sytuacji stresu: poszukują zastępczej satysfakcji, reagują rezygnacją, biernością, poczuciem przygnębienia i beznadziejności, obwiniają siebie, użalają się nad sobą i poszukują wsparcia, długotrwale koncentrują się na doświadczanym cierpieniu, izolują się lub też reagują agresją i spożywają alkohol.

Słowa kluczowe: uzależnienie od telefonu komórkowego, radzenie sobie ze stresem

\section{Introduction}

Problematic use of the mobile phone is classified by researchers $[1,2,3,4,5]$ as a so-called technological addiction. Grant et al. [6], Park and Lee [7] and Smetaniuk [8] believe that problematic use of the mobile phone shares patterns of behavior with impulse control disorders such as pathological gambling. The general opinion among researchers is that problematic mobile phone use should be considered as a separate behavioral disorder. However, at present, despite the efforts of some investigators [9], mobile phone addiction does not feature in classifications of mental disorders and diseases (ICD-10, DSM-V) as a separate category of disorders $[10,11]$. Therefore, researchers are forced to try to develop their own definitions of this disorder. The following terms are found in the literature: mobile phone problematic use [5, 12,13,14,15], mobile phone addiction $[9,16,17,18,19]$, mobile phone abuse [20,21], mobile phone overuse [22], and mobile phone dependence [23].

Mobile phone overuse [24] is complete preoccupation with one's own phone in inappropriate situations. Individuals who show symptoms of problematic mobile phone use or are dependent on the mobile phone admit to having their phone with them at all times and to being absorbed in thinking about it when they are not using it, which leads to difficulty completing their daily tasks. They treat mobile phone use as a way of coping with difficult situations, and believe that the fact of receiving calls or messages is a proof of appreciation and acceptance on the part of their surroundings [25]. People addicted to mobile 
phone develop a tolerance i.e. a need to spend increasing amounts of time using this device in order to achieve a certain level of satisfaction $[5,9,26]$ and to always have the latest model of a phone [9]. Many authors [5,12,27,28,29,30] have found that people dependent on the mobile phone experience unpleasant emotions (e.g. stress, anger, uneasiness, anxiety) in situation in which, for various reasons, they cannot use their phone (e.g. when staying in places where mobile phone use is prohibited, when the person they are trying to reach is out of range or when they have left their phone at home). Walsh et al. [25] emphasize that at times when they are unable to use a mobile phone, mobile phone addicts experience discomfort associated with a sense of disconnectedness from other people.

Numerous authors $[14,27,31,32]$ report that mobile phone overuse disturbs normal functioning of a person in various areas of everyday life, leading to conflicts with family and friends, financial problems, sleep interference (checking calls and messages during the night), dangerous use (talking on the phone while driving), etc. Billieux et al. [27] and Roberts and Pirog [33] point out that the lack of control over the use of a mobile phone (i.e. the inability to stop using a phone in response to certain situations, signs or emotional states) is a key feature of dysfunctional mobile phone use. King et al. [34] and Billieux et al. [35] report cases of people who have lost control over their mobile phone use and had to reach for their phone every time they experienced emotional tension.

Problematic mobile phone use is thus identified with the inability to regulate the frequency of mobile phone use which leads to many negative outcomes in everyday life, as well as social, behavioral, and affective problems $[14,35]$. These views are consistent with the opinion of Chóliz [9], who suggests that problematic mobile phone use among adolescents interferes with their personal, school and social lives. Shambare et al. [36] go as far as to claim that the mobile phone is "possibly the biggest nondrug addiction of the 21 st century."

According to a survey conducted by CBOS (Centre for Public Opinion Research) [37] among 1040 adult Poles, $91 \%$ of the respondents use the mobile phone. The same CBOS survey [37] demonstrates that apart from making calls (100\% of respondents), and sending and receiving text messages (78\%), Poles also use mobile phones to take pictures $(57 \%)$ and record videos (31\%) and sounds (13\%). The Polish respondents also use their phones to go online: to browse websites (37\%), check e-mail (28\%) and weather forecasts $(28 \%)$, as well as check their social media accounts $(22 \%)$. At the same time, $33 \%$ of the respondents report using their phones to listen to music, and $20 \%$ use them to watch videos and play games (20\%). Only a small group of respondents (12\%) edit text files or images using a mobile phone. Roberts et al. [38] emphasize that stu- dents most often use the mobile phone for texting, sending e-mails, social networking, and making calls.

In the opinion of Billieux and colleagues [35], dysfunctional use of the mobile phone involves using it as a tool of emotional regulation, as it can help reduce the level of anxiety resulting from recurrent negative thoughts.

The literature of the subject offers no extensive studies on coping preferences of individuals addicted to the mobile phone and those at risk of being addicted.

The aim of the present study was to provide an answer to the question of whether, and what, differences in stress coping strategies could be found between students at risk and not at risk of mobile phone addiction

\section{Methods and participants}

The following instruments were used:

- a sociodemographic questionnaire by Pawłowska and Potembska [39];

- the Mobile Phone Addiction Assessment Questionnaire (Kwestionariusz do Badania Uzależnienia od Telefonu Komórkowego, KBUTK) by Pawłowska and Potembska [19], which consists of 33 items on four scales: Acceptance and Closeness, Addiction to Mobile Phone Features, Addiction to Text Messaging and Voice Calls, and Indirect Communication. Persons whose score on the global KBUTK scale is within the range of 31 to 69 points (i.e. within the range from the mean score to plus two standard deviations from the mean) are considered to be at risk of mobile phone addiction. Individuals whose score is two or more deviations from the mean (70 points and above) are considered addicted [40];

- the Coping with Stress Questionnaire (SVF) by Janke, Erdmann, and Boucsein, translated into Polish by Januszewska, is a tool used to test the possible responses of a person to situations in which he or she has experienced harm from someone or something and has, for that reason, felt internal agitation or been put off balance [41]. SVF measures 19 coping strategies;

The instruments used in the study meet the criteria for psychometric validity and reliability $[19,40,41,42]$.

The questionnaires described above were used to survey a group of 408 university students, aged 19 to 28 years. Students were assigned to addiction/risk groups on the basis of their general KBUTK scores [19]. In the group under study, none of the respondents met the KBUTK criteria for mobile phone addiction (overall score of 70 points and above); the criteria for risk of mobile phone addiction were met by a total of 151 persons $337.01 \%$ of the entire participant group) whose score on the general scale of KBUTK was in the range from 31 to 69 points: 38 men $(25.17 \%)$ and 113 women $(74.83 \%)$. 
The control group consisted of 257 respondents (62.99\% of the entire participant group) who were not at risk of mobile phone addiction (a KBUTK score of 30 points or less). Among non-risk participants, there were 61 men $(23.74 \%)$ and 196 women (76.26\%).

\section{Results}

In order to answer the research question, the SVF scores obtained by participants at risk of mobile phone addiction (151 individuals) were compared to those of the control (not-at-risk) participants (257 individuals) using Student's t-test (Table 1).

Students at risk of mobile phone addiction obtained statistically significantly higher scores than the control participants on the following SVF scales: Substitute Gratification, Escape, Social Withdrawal, Rumination, Resignation, Selfpity, Self-blame, Aggression, Drug Use, Denial of Guilt, and Need for Social Support (Table 1).

The results indicate that in a situation of stress, students at risk of mobile phone addiction are significantly more likely than those in the control group to show passivity in the face of a problematic situation. Easy acceptance of failure can lead to resignation and a strong sense of despondency and hopelessness. Respondents at risk of mobile phone addiction significantly more often than their not-at-risk peers report blaming themselves for the existing difficult situation and feeling sorry for themselves; they are also more likely to turn their experiences of suffering over and over in their minds long after the events took place, which handicaps their ability to focus on current matters. They see other people as "bothersome", which is why they avoid interpersonal involvement.

It is also noteworthy that their helplessness in the face of stressful events may induce people at risk of mobile phone addiction to engage in aggressive actions directed at other people or objects, as well as self-aggressive behavior. To unwind in a problematic situation, these individuals are more likely than the controls to resort to sedatives and sleeping pills, and also tend to increase their smoking or to abuse alcohol.

On the other hand, the at-risk respondents significantly more often than the controls cope with stress by looking for the source of their difficulties outside of themselves. In situations generating a strong mental stress, they are significantly more likely to plan and put into practice behaviors which allow them to "escape" from the unpleasant consequences of the situation, look for whatever pleasure that may reduce their emotional tension, or turn to others for help, advice, and support.

Table 2 shows the results of a Student's t-test comparing coping strategies in female participants at risk and not at risk of mobile phone addiction.

The results of statistical analysis indicate that female students at risk of mobile phone addiction are significantly more likely to use non-adaptive ways of coping with stress compared to female controls.

In the face of difficulties, female students at risk of mobile phone addiction significantly more often than their not-at-risk peers forgo any efforts to remove the causes of the difficult situation they are experiencing and, at the same time, are significantly more likely to look inside themselves for the causes and sources of the mistake the consequences of which are so painfully felt. In this group of respondents (at-risk females), such a state of affairs is accompanied by a whole gamut of pessimistic visions of the future and relentless brooding on the experienced state of suffering. The coping strategies used by students at risk of mobile phone addiction are "amplified" by their constant rumination over the content of the difficult situation, making it difficult for them to effectively adapt.

Table 1. A comparison of coping strategies in students at risk and not at risk of mobile phone addiction

\begin{tabular}{|c|c|c|c|c|c|c|}
\hline \multirow{2}{*}{ SVF scales } & \multicolumn{2}{|c|}{ Persons at risk } & \multicolumn{2}{|c|}{ Persons not at risk } & \multirow{2}{*}{$\mathrm{t}$} & \multirow{2}{*}{$\mathrm{p}$} \\
\hline & $\mathrm{M}$ & SD & $\mathrm{M}$ & SD & & \\
\hline Minimization & 11.56 & 3.65 & 11.57 & 3.48 & -0.02 & ns \\
\hline Self-aggrandizement & 8.18 & 3.94 & 8.40 & 3.85 & -0.55 & ns \\
\hline Denial of Guilt & 9.82 & 2.86 & 8.96 & 2.98 & 2.84 & 0.005 \\
\hline Distraction & 11.86 & 3.38 & 11.62 & 3.55 & 0.68 & ns \\
\hline Substitute Gratification & 11.89 & 4.04 & 10.33 & 4.26 & 3.63 & 0.001 \\
\hline Seeking Self-affirmation & 10.60 & 3.77 & 10.35 & 3.76 & 0.65 & ns \\
\hline Situation Control & 13.15 & 3.46 & 13.51 & 3.59 & -0.99 & ns \\
\hline Response Control & 13.25 & 3.58 & 13.32 & 3.11 & -0.23 & ns \\
\hline Positive Self-instruction & 11.65 & 3.64 & 11.80 & 3.41 & -0.43 & ns \\
\hline Need for Social Support & 13.24 & 5.13 & 12.22 & 4.47 & 2.11 & 0.036 \\
\hline Avoidance & 12.87 & 2.89 & 12.65 & 3.17 & 0.71 & ns \\
\hline Escape & 11.83 & 4.49 & 9.44 & 4.09 & 5.50 & 0.001 \\
\hline Social Withdrawal & 8.99 & 4.27 & 6.75 & 4.40 & 5.00 & 0.001 \\
\hline Rumination & 15.09 & 4.97 & 12.81 & 5.10 & 4.40 & 0.001 \\
\hline Resignation & 11.97 & 3.48 & 9.93 & 3.50 & 5.72 & 0.001 \\
\hline Self-pity & 11.83 & 3.84 & 9.23 & 4.12 & 6.32 & 0.001 \\
\hline Self-blame & 12.11 & 4.11 & 10.04 & 4.25 & 4.81 & 0.001 \\
\hline Aggression & 9.22 & 4.07 & 6.80 & 3.75 & 6.10 & 0.001 \\
\hline Dependence & 2.96 & 3.17 & 2.10 & 2.70 & 2.79 & 0.006 \\
\hline
\end{tabular}


Table 2. A comparison of coping strategies in women at risk and not at risk of mobile phone addiction

\begin{tabular}{|c|c|c|c|c|c|c|}
\hline \multirow{2}{*}{ SVF scales } & \multicolumn{2}{|c|}{ Women at risk } & \multicolumn{2}{|c|}{ Women not at risk } & \multirow{2}{*}{$\mathrm{t}$} & \multirow{2}{*}{$\mathrm{p}$} \\
\hline & $\mathrm{M}$ & SD & $\mathrm{M}$ & SD & & \\
\hline Minimization & 11.42 & 3.73 & 11.71 & 3.47 & -0.69 & ns \\
\hline Self-aggrandizement & 7.80 & 3.94 & 7.98 & 3.74 & -0.41 & ns \\
\hline Denial of Guilt & 9.78 & 2.82 & 8.97 & 2.96 & 2.36 & 0.019 \\
\hline Distraction & 12.00 & 3.49 & 11.86 & 3.51 & 0.35 & ns \\
\hline Substitute Gratification & 12.18 & 3.93 & 10.60 & 4.36 & 3.18 & 0.002 \\
\hline Seeking Self-affirmation & 10.48 & 3.79 & 10.40 & 3.87 & 0.16 & ns \\
\hline Situation Control & 13.12 & 3.67 & 13.35 & 3.57 & -0.54 & ns \\
\hline Response Control & 13.14 & 3.55 & 13.43 & 3.02 & -0.75 & ns \\
\hline Positive Self-instruction & 11.69 & 3.76 & 11.82 & 3.44 & -0.30 & ns \\
\hline Need for Social Support & 13.64 & 4.92 & 12.90 & 4.40 & 1.35 & ns \\
\hline Avoidance & 13.00 & 2.97 & 12.78 & 3.11 & 0.62 & $\mathrm{~ns}$ \\
\hline Escape & 12.13 & 4.48 & 9.66 & 4.10 & 4.93 & 0.001 \\
\hline Social Withdrawal & 9.14 & 4.34 & 6.90 & 4.41 & 4.32 & 0.001 \\
\hline Rumination & 15.55 & 4.83 & 13.33 & 5.01 & 3.81 & 0.001 \\
\hline Resignation & 12.41 & 3.28 & 10.16 & 3.43 & 5.64 & 0.001 \\
\hline Self-pity & 11.96 & 3.85 & 9.54 & 4.09 & 5.12 & 0.001 \\
\hline Self-blame & 12.27 & 4.10 & 10.46 & 4.29 & 3.61 & 0.001 \\
\hline Aggression & 9.50 & 4.02 & 7.00 & 3.89 & 5.39 & 0.001 \\
\hline Dependence & 2.75 & 2.91 & 2.20 & 2.71 & 1.67 & ns \\
\hline
\end{tabular}

Table 3. A comparison of coping strategies in men at risk and not at risk of mobile phone addiction

\begin{tabular}{|c|c|c|c|c|c|c|}
\hline \multirow{2}{*}{ SVF scales } & \multicolumn{2}{|c|}{ Men at risk } & \multicolumn{2}{|c|}{ Men not at risk } & \multirow{2}{*}{$\mathrm{t}$} & \multirow{2}{*}{$\mathrm{p}$} \\
\hline & M & SD & $\mathrm{M}$ & SD & & \\
\hline Minimization & 11.97 & 3.40 & 11.11 & 3.49 & 1.20 & ns \\
\hline Self-aggrandizement & 9.32 & 3.79 & 9.74 & 3.94 & -0.53 & ns \\
\hline Denial of Guilt & 9.95 & 3.03 & 8.95 & 3.09 & 1.57 & ns \\
\hline Distraction & 11.45 & 3.04 & 10.85 & 3.61 & 0.85 & ns \\
\hline Substitute Gratification & 11.03 & 4.30 & 9.48 & 3.85 & 1.86 & ns \\
\hline Seeking Self-affirmation & 10.95 & 3.73 & 10.16 & 3.39 & 1.08 & ns \\
\hline Situation Control & 13.24 & 2.82 & 14.02 & 3.62 & -1.13 & ns \\
\hline Response Control & 13.55 & 3.69 & 12.98 & 3.39 & 0.79 & ns \\
\hline Positive Self-instruction & 11.53 & 3.30 & 11.75 & 3.31 & -0.33 & ns \\
\hline Need for Social Support & 12.05 & 5.60 & 10.02 & 3.98 & 1.96 & 0.055 \\
\hline Avoidance & 12.50 & 2.65 & 12.25 & 3.35 & 0.40 & ns \\
\hline Escape & 10.95 & 4.45 & 8.74 & 4.00 & 2.56 & 0.012 \\
\hline Social Withdrawal & 8.53 & 4.06 & 6.28 & 4.37 & 2.56 & 0.012 \\
\hline Rumination & 13.74 & 5.22 & 11.16 & 5.08 & 2.43 & 0.017 \\
\hline Resignation & 10.68 & 3.77 & 9.18 & 3.62 & 1.98 & 0.051 \\
\hline Self-pity & 11.47 & 3.84 & 8.25 & 4.11 & 3.90 & 0.001 \\
\hline Self-blame & 11.66 & 4.17 & 8.69 & 3.85 & 3.61 & 0.001 \\
\hline Aggression & 8.37 & 4.15 & 6.15 & 3.21 & 2.99 & 0.004 \\
\hline Dependence & 3.58 & 3.80 & 1.77 & 2.68 & 2.56 & 0.013 \\
\hline
\end{tabular}

The results (Table 2) obtained in the present study also show that female students at risk of mobile phone addiction are significantly more likely to show aggressive behavior towards others or towards themselves, withdraw from social interactions, escape from problems, and seek substitute gratification (e.g. through watching TV).

The present study also compares the coping preferences of men at risk and those not at risk of mobile phone addiction (Table 3).
Male students at risk of mobile phone addiction are significantly more likely than men from the control group to blame themselves for the difficult situation they have found themselves in, to pity themselves, to ruminate over their own suffering, and to give up any efforts to resolve their problem, which may lead to persistent feelings of dejection and hopelessness. Men at risk of mobile phone addiction significantly more often than their not-at-risk counterparts have difficulty taking new, constructive action; they are also significantly more likely to be ab- 
sorbed in thoughts about the recently experienced problems and to seek help and support from others.

The results also indicate that men at risk of mobile phone addiction are more likely than male controls to react to stress with aggression towards themselves and others, turn to alcohol and other psychoactive agents, avoid contact with people, and plan and put into practice behaviors aimed at "escaping" the difficult situation.

\section{Results and discussion}

The results of the present study show that students at risk of mobile phone addiction, compared to their normal, notat-risk peers, are more likely to cope with stress using emotion-focused and avoidant strategies by seeking substitute gratification, reacting with resignation, passivity, dejection and hopelessness, blaming themselves, pitying themselves and looking for support. They also tend to ruminate over their suffering, withdraw from social interactions, react with aggression or take to drinking. These results are consistent with the opinion of Roberts and colleagues [43], who believe that the use of a mobile phone in a situation of stress can be regarded as a form of substitute gratification or as a kind of addiction. Moreover, investigators note that people with severe neuroticism may use the mobile phone as a way of coping with stress and anxiety [44].

Some researchers of the subject $[45,46,47]$ believe that excessive mobile phone use may be an attempt to escape from problems and unpleasant emotions, and the pleasure experienced when using the phone contributes to developing a permanent coping strategy. According to escape theory, which is used to explain compulsive buying $[45,46,47]$, dependence on one's phone, just like dependence on shopping - is a "second-order/secondary addiction", which means that the use of the phone is an attempt to escape from another, more important problem, boredom, low self-esteem, difficulties in interpersonal relationships, etc.

Moreover, problematic mobile phone use, according to Billieux et al. [48] is dictated by the need to ensure the support of the surrounding people, and the mobile phone is an instrument that can help a person satisfy this need. Using a mobile phone and its features may also be consid- ered as a way of responding to stress, diverting attention from problems by seeking substitute gratification, especially in connection with the possibilities offered by a smartphone of going online, playing computer games, listening to music, etc. [38]. At the same time, many researchers $[49,50,51]$ dealing with addiction to computer games and the Internet note that excessive gaming may be a non-adaptive way of coping with stress. Wan and Chiou [52] claim that games may be treated by players as means of emotional coping with stress as they allow these persons to escape from loneliness, isolation and boredom, as well as to relax and relieve anger and frustration.

Because the smartphone provides unlimited access to the Internet, it is worth drawing attention to the opinion of Li et al. [53], who emphasize that in stressful situations, individuals who use the Internet pathologically are more likely than those not at risk of Internet addiction to blame themselves for failure, avoid problems, fantasize about their failures, use rationalization, and abuse alcohol and other psychoactive agents. On the other hand, Seepersad [54] believes that ruminative coping correlates with the use of the Internet for entertainment purposes, avoidant coping is connected with frequent use of instant messengers and e-mail, while searching for substitute gratification in a stressful situation is associated with frequent sending of e-mails [54].

Research suggests that the necessity of meeting the challenges of everyday life increases an individual's sense of being lost, thus causing stress and negative emotions. Non-adaptive coping enhances mental discomfort and may embroil a person in various kinds of problematic behavior, also increasing the risk of developing a dependence on the mobile phone.

\section{Conclusions}

1. Compared to controls, individuals at risk of mobile phone addiction are more likely to cope with stress by seeking substitute gratification, reacting with resignation, passivity, dejection and hopelessness, blaming themselves, pitying themselves and looking for support. They also tend to ruminate over their suffering, withdraw from social interactions, react with aggression or take to drinking.

\section{Wstęp}

Problematyczne używanie telefonu komórkowego zaliczane jest przez badaczy $[1,2,3,4,5]$ do tzw. uzależnienień technologicznych. Grant i wsp. [6], Park i Lee [7] oraz Smetaniuk [8] uważają, że problematyczne korzystanie z telefonu komórkowego ma zbliżone wzorce zachowań do zaburzeń kontroli impulsów, podobnych do patologicznego hazardu. Powinno być uważane za oddzielne zaburzenie behawioralne. Jednakże obecnie, mimo starań niektórych badaczy [9], brakuje w klasyfikacjach zaburzeń i chorób psychicznych (ICD-10; DSM-V), takiej kategorii zaburzeń, jak uzależnienie od telefonu komórkowego $[10,11]$. Wobec tego wielu badaczy zmuszonych jest do podejmowania prób tworzenia własnej definicji tego zaburzenia. Stosują następujące określenia: problematyczne używanie telefonu komórkowego (mobile phone problematic use) $[5,12,13,14,15]$, uzależnienie od telefonu komórkowego (mobile phone addiction) $[9,16,17,18,19]$, naużywanie telefo- 
nu komórkowego (mobile phone abuse) [20,21], nadmierne używanie telefonu komórkowego (mobile phone overuse) [22], zależność od telefonu komórkowego (mobile phone dependence) [23].

Nadmierne korzystanie z telefonu komórkowego [24], obejmuje całkowite zaabsorbowanie własnym telefonem w sytuacji, kiedy nie można $\mathrm{z}$ niego korzystać. Osoby problematycznie korzystające $\mathrm{z}$ telefonu komórkowego lub od niego uzależnione przyznają, że mają stale telefon komórkowy przy sobie, są pochłonięte myśleniem o nim kiedy z niego nie korzystają, w konsekwencji doświadczają trudności związanych $\mathrm{z}$ wykonywaniem aktualnych zajęć. Korzystanie z telefonu komórkowego zaczyna być przez nie traktowane jako sposób radzenia sobie w każdej trudnej sytuacji, a otrzymywanie połączeń lub wiadomości są, ich zdaniem - dowodem doceniania i akceptacji ze strony otoczenia [25]. U osób uzależnionych od telefonu komórkowego pojawia się tolerancja oznaczająca potrzebę zwiększania częstotliwości i wydłużania czasu korzystania $\mathrm{z}$ tego urządzenia $\mathrm{w}$ celu osiągnięcia określonego poziomu satysfakcji $[5,9,26]$ oraz zastępowania go najnowszymi modelami, które pojawiają się na rynku [9]. Z badań wielu autorów [5,12,27,28,29,30] wynika, że osoby uzależnione od telefonu komórkowego doświadczały nieprzyjemnych emocji (np. stresu, złości, niepokoju, lęku) w sytuacji, kiedy $\mathrm{z}$ różnych względów (pozostawanie w miejscach, gdzie jest zakaz korzystania z telefonu; kiedy osoba, do której próbowano się dodzwonić była poza zasięgiem lub gdy ktoś zostawił telefon w domu), nie mogły skorzystać ze swojego telefonu. Walsh i wsp. [25] podkreślają, że w sytuacji niemożności korzystania z telefonu komórkowego, osoby doświadczają dyskomfortu związanego z poczuciem izolacji.

Wielu autorów [14,27,31,32] wskazuje, że nadmierne używanie telefonu zakłóca funkcjonowanie jednostki w różnych obszarach życia codziennego, powodując konflikty z rodziną i przyjaciółmi, problemy finansowe, zaburzenia snu (ze względu na sprawdzanie połączeń i wiadomości w ciągu nocy), niebezpieczne użycie (rozmowy przez telefon komórkowy w trakcie prowadzenia samochodu) itp. Billieux i wsp. [27] oraz Roberts i Pirog [33] podkreślają, że brak kontroli nad użyciem telefonu komórkowego (tj. niemożność zaprzestania użycia w odpowiedzi na pewne sytuacje, sygnały lub stany emocjonalne) jest kluczową cechą dysfunkcyjnego korzystania z telefonu komórkowego. King i wsp. [34] oraz Billieux i wsp. [35] piszą o przypadkach, gdy osoby traciły kontrolę nad korzystaniem $\mathrm{z}$ telefonu komórkowego i każdorazowo w sytuacji kiedy doświadczały napięcia emocjonalnego sięgały po telefon komórkowy.

Problematyczne używanie telefonu komórkowego utożsamiane jest więc $\mathrm{z}$ niezdolnością do regulowania przez jednostkę częstości używania telefonu, które prowadzi do wielu negatywnych konsekwencji w życiu co- dziennym, a także problemów społecznych, behawioralnych i afektywnych $[14,35]$. Poglądy te są spójne ze zdaniem Chóliza [9], który sugeruje, że problematyczne korzystanie z telefonu komórkowego w grupie adolescentów zakłóca ich życie osobiste oraz szkolne i społeczne. Shambare i wsp. [36] twierdzą wręcz, że telefon komórkowy jest „prawdopodobnie największym uzależnieniem niesubstancjalnym XXI wieku".

Według badania CBOS [37] przeprowadzonego w grupie 1040 dorosłych Polaków wynika, że z telefonu komórkowego korzysta 91\% respondentów. W tym samym badaniu CBOS [37] wykazano, że telefon komórkowy -poza prowadzeniem rozmów (100\%) i wysyłaniem i odbieraniem za ich pośrednictwem wiadomości SMS (78\%), służy Polakom również do robienia zdjęć (57\%), nagrywania filmów wideo (31\%), rejestrowania dźwięków (13\%). Przy pomocy telefonu komórkowego badani korzystali również z Internetu: przeglądali strony internetowe (37\%), pocztę elektroniczną (28\%), prognozę pogody (28\%), a także konta w serwisie społecznościowym (22\%). Jednocześnie telefon był wykorzystywany przez 33\% respondentów do słuchania muzyki, oglądania materiałów wideo i grania w gry (20\% respondentów). Nieliczni (12\%) edytowali przy pomocy telefonu komórkowego pliki tekstowe lub zdjęcia. Roberts i wsp. [38] podkreślają, że najczęściej wykonywanymi czynnościami przy użyciu telefonu komórkowego wśród studentów jest pisanie SMS-ów, wysyłanie e-maili, korzystanie $\mathrm{z}$ portali społecznościowych i prowadzenie rozmów przy użyciu telefonu komórkowego.

Zdaniem Billieux i wsp. [35] osoby korzystające z telefonu komórkowego w sposób dysfunkcjonalny wykorzystują go jako narzędzie regulowania własnych stanów emocjonalnych, gdyż służy on obniżaniu poziomu niepokoju wynikającego z nawracających negatywnych myśli.

W literaturze przedmiotu ciągle brak szeroko zakrojonych badań, które wskazywałyby jakie preferencje w zakresie stosowanych strategii radzenia sobie ze stresem charakteryzują osoby uzależnione i zagrożone uzależnieniem od telefonu komórkowego.

Celem niniejszej pracy było udzielenie odpowiedzi na następujący problem badawczy: czy i jakie różnice występują w zakresie sposobów radzenia sobie ze stresem między studentami zagrożonymi i niezagrożonymi uzależnieniem od telefonu komórkowego?

\section{Metody i grupa badana}

Zastosowano następujące metody badawcze:

- Ankietę socjodemograficzną autorstwa B. Pawłowskiej i E. Potembskiej [39];

- Kwestionariusz do Badania Uzależnienia od Telefonu Komórkowego (KBUTK), autorstwa B. Pawłowskiej i E. Potembskiej [19], który składa się z 33 itemów tworzących 4 skale: potrzeba akceptacji i bliskości, uza- 
leżnienie od funkcji aparatu telefonicznego, uzależnienie od SMS-ów i rozmów, komunikacja pośrednia. Za osoby zagrożone uzależnieniem od telefonu komórkowego uznano te, które uzyskały w skali ogólnej KBUTK wyniki w przedziale od 31 do 69 punktów, to jest w granicach od wyniku średniego do plus 2 odchylenia standardowego od średniej. Za osoby uzależnione od telefonu komórkowego uznano badanych, którzy uzyskali $\mathrm{w}$ badaniu KBUTK wynik równy lub powyżej 2 odchylenia standardowego od średniej - 70 punktów i powyżej [40];

- Kwestionariusz Radzenia Sobie ze Stresem (KRS), autorstwa W. Janke, G. Erdmann, W. Boucsein, w polskim tłumaczeniu E. Januszewskiej, jest narzędziem badania możliwych reakcji osoby, które daje się zaobserwować w sytuacjach, w jakich doznała ona krzywdy wyrządzonej przez kogoś lub przez coś i z tego powodu odczuła wewnętrzne pobudzenie lub wytrącenie ze stanu równowagi [41]. Służy do pomiaru 19 sposobów radzenia sobie ze stresem;

Zastosowane narzędzia spełniają kryteria trafności i rzetelności psychometrycznej [19,40,41,42].

Opisanymi wyżej kwestionariuszami przebadano grupę 408 osób, w wieku od 19 do 28 lat. Studenci byli następnie kwalifikowani do grup na postawie uzyskanego przez nich wyniku ogólnego w KBUTK, autorstwa Pawłowskiej i Potembskiej [19]. W badanej grupie żaden respondent nie spełniał kryteriów uzależnienia od telefonu komórkowego w ujęciu KBUTK (wynik ogólny 70 punktów i powyżej), kryteria zagrożenia uzależnieniem od telefonu komórkowego spełniało łącznie 151 osób $(37,01 \%$ całej badanej grupy studentów) - otrzymali oni odpowiednio w skali ogólnej KBUTK wyniki w przedziale od 31 do 69 punktów: 38 mężczyzn (25,17\%) i 113 kobiet (74,83\%).

Grupę kontrolną stanowiło 257 badanych $(62,99 \%$ całej badanej grupy studentów) niezagrożonych uzależnieniem od telefonu komórkowego (uzyskali w KBUTK wynik 30 punktów lub niższy). Wśród niezagrożonych uzależnieniem od telefonu komórkowego było 61 mężczyzn $(23,74 \%)$ i 196 kobiet $(76,26 \%)$.

\section{Wyniki}

W celu udzielenia odpowiedzi na pytanie badawcze porównano osoby zagrożone uzależnieniem od telefonu komórkowego (151 osób) z osobami niezagrożonymi tym uzależnieniem (257 osób) testem t-Studenta, w zakresie wyników uzyskanych w skalach Kwestionariusza Radzenia Sobie ze Stresem KRS (tab.1).

Studenci zagrożeni uzależnieniem od telefonu komórkowego w porównaniu z badanymi niezagrożonymi tym uzależnieniem, uzyskali istotnie statystycznie wyższe wyniki w skalach KRS: Zastępcza satysfakcja, Tendencja ucieczkowa, Izolowanie się od ludzi, Dalsze zajmowanie się w myślach, Rezygnacja, Użalanie się nad sobą, Obwinianie siebie, Agresja, Uzależnienie od leków lub innych związków chemicznych, Obrona przed winą, Poszukiwanie społecznego wsparcia (tab.1).

Tabela 1. Porównanie studentów zagrożonych i niezagrożonych uzależnieniem od telefonu komórkowego w zakresie sposobów radzenia sobie ze stresem

\begin{tabular}{|l|c|c|c|c|c|c|}
\hline \multirow{2}{*}{\multicolumn{1}{|c|}{ Skale KRS }} & \multicolumn{2}{c|}{ Zagrożeni } & \multicolumn{2}{c|}{ Niezagrożeni } & \multirow{2}{*}{$\mathrm{t}$} & \multirow{2}{*}{$\mathrm{p}$} \\
\cline { 2 - 6 } & $\mathrm{M}$ & $\mathrm{sd}$ & $\mathrm{M}$ & $\mathrm{sd}$ & & $\mathrm{n}$ \\
\hline Bagatelizacja & 11,56 & 3,65 & 11,57 & 3,48 & $-0,02$ & $\mathrm{ni}$ \\
\hline Porównywanie z innymi & 8,18 & 3,94 & 8,40 & 3,85 & $-0,55$ & $\mathrm{ni}$ \\
\hline Obrona przed winą & 9,82 & 2,86 & 8,96 & 2,98 & 2,84 & 0,005 \\
\hline Odwrócenie uwagi & 11,86 & 3,38 & 11,62 & 3,55 & 0,68 & $\mathrm{ni}$ \\
\hline Zastępcza satysfakcja & 11,89 & 4,04 & 10,33 & 4,26 & 3,63 & 0,001 \\
\hline Poszukiwanie samopotwierdzenia & 10,60 & 3,77 & 10,35 & 3,76 & 0,65 & $\mathrm{ni}$ \\
\hline Próba kontroli przebiegu sytuacji & 13,15 & 3,46 & 13,51 & 3,59 & $-0,99$ & $\mathrm{ni}$ \\
\hline Próba kontroli swoich reakcji & 13,25 & 3,58 & 13,32 & 3,11 & $-0,23$ & $\mathrm{ni}$ \\
\hline Pozytywne instruowanie siebie & 11,65 & 3,64 & 11,80 & 3,41 & $-0,43$ & $\mathrm{ni}$ \\
\hline Poszukiwanie społecznego wsparcia & 13,24 & 5,13 & 12,22 & 4,47 & 2,11 & 0,036 \\
\hline Tendencja unikowa & 12,87 & 2,89 & 12,65 & 3,17 & 0,71 & $\mathrm{ni}$ \\
\hline Tendencja ucieczkowa & 11,83 & 4,49 & 9,44 & 4,09 & 5,50 & 0,001 \\
\hline Izolowanie się od ludzi & 8,99 & 4,27 & 6,75 & 4,40 & 5,00 & 0,001 \\
\hline Dalsze zajmowanie się w myślach & 15,09 & 4,97 & 12,81 & 5,10 & 4,40 & 0,001 \\
\hline Rezygnacja & 11,97 & 3,48 & 9,93 & 3,50 & 5,72 & 0,001 \\
\hline Użalanie się nad sobą & 11,83 & 3,84 & 9,23 & 4,12 & 6,32 & 0,001 \\
\hline Obwinianie siebie & 12,11 & 4,11 & 10,04 & 4,25 & 4,81 & 0,001 \\
\hline Agresja & 9,22 & 4,07 & 6,80 & 3,75 & 6,10 & 0,001 \\
\hline Uzależnienie & 2,96 & 3,17 & 2,10 & 2,70 & 2,79 & 0,006 \\
\hline
\end{tabular}


Otrzymane wyniki (tab. 1) informują, że w sytuacji stresu studenci zagrożeni uzależnieniem od telefonu komórkowego istotnie częściej niż osoby z grupy kontrolnej (niezagrożeni tym uzależnieniem) przejawiają bierność w obliczu zaistniałego problemu. Łatwe zaakceptowanie porażki może powodować rezygnację, silne poczucie przygnębienia i beznadziejności. Badani z grupy zagrożonych omawianym uzależnieniem istotnie częściej w porównaniu do grupy kontrolnej, w obliczu trudności obwiniają siebie za zaistniały stan rzeczy, użalając się nad własnym losem, a ich koncentrację na doświadczanym cierpieniu pogłębia fakt, iż długo po zaistniałym zdarzeniu powracają do niego w myślach, co ogranicza ich możliwość koncentracji na bieżących sprawach. Inni ludzie w zaistniałej sytuacji spostrzegani są jako „uciążliwi” wobec czego badani unikają kontaktów interpersonalnych.

Na uwagę zasługuje również fakt, iż bezradność zagrożonych uzależnieniem od telefonu komórkowego wobec zdarzeń stresogennych może stanowić częsty motyw agresywnych działań kierowanych w kierunku innych ludzi czy przedmiotów, a także pojawiających się zachowań autoagresywnych. W celu poszukiwania uspokojenia w sytuacji problemowej częściej niż badani niezagrożeni tym uzależnieniem sięgają po leki uspokajające, nasenne, skłaniają się by więcej palić, czy nadużywają alkoholu.

Z drugiej strony badani z grupy zagrożonych uzależnieniem od telefonu komórkowego istotnie częściej w porównaniu do grupy kontrolnej, radzą sobie ze stresem upatrując poza sobą źródła trudności. W sytuacji generującej silne napięcie psychiczne istotnie częściej planują i realizują zachowania, które umożliwią „ucieczkę” przed przykrymi jej konsekwencjami, poszukują jakiejkolwiek przyjemności redukującej napięcie emocjonalne lub zwracają się do innych osób z prośbą o pomoc, radę, wsparcie.
W tabeli 2 przedstawiono wyniki testu t-Studenta, przy pomocy, którego porównano studentki zagrożone i niezagrożone uzależnieniem od telefonu komórkowego ze względu na sposoby radzenia sobie ze stresem.

Uzyskane na podstawie analiz statystycznych wyniki informują, że studentki zagrożone uzależnieniem od telefonu komórkowego istotnie częściej stosują nieadaptacyjne sposoby radzenia sobie ze stresem w porównaniu $\mathrm{z}$ badanymi kobietami niezagrożonymi tym uzależnieniem (grupa kontrolna kobiet).

W obliczu trudności studentki zagrożone uzależnieniem od telefonu komórkowego istotnie częściej niż kobiety z grupy kontrolnej rezygnują z wszelkich prób usunięcia przyczyn zaistniałej, trudnej sytuacji, a jednocześnie istotnie częściej upatrują w sobie przyczyny i źródła błędu, którego konsekwencje są tak dotkliwie odczuwalne. Takiemu stanowi rzeczy w grupie zagrożonych kobiet towarzyszy wachlarz pesymistycznych wizji dotyczących przyszłości oraz bezustanna koncentracja na doświadczanym stanie cierpienia. Opisane sposoby radzenia sobie ze stresem stosowane przez zagrożone uzależnieniem studentki są „wzmacniane” przez istotnie częstsze niż wśród badanych z drugiej grupy, nawracające analizowanie treści zaistniałej trudnej sytuacji, co utrudnia efektywne przystosowanie się.

Otrzymane wyniki badań wskazują również, że studentki zagrożone uzależnieniem od telefonu komórkowego istotnie częściej niż z grupy kontrolnej prezentują zachowania agresywne wobec innych lub autoagresywne, izolują się od ludzi, uciekają od problemów oraz poszukują zastępczej satysfakcji, np. oglądają telewizję.

W pracy porównano również sposoby radzenia sobie ze stresem preferowane przez mężczyzn zagrożonych i niezagrożonych uzależnieniem od telefonu komórkowego (tab.3).

Tab. 2. Porównanie kobiet zagrożonych i niezagrożonych uzależnieniem od telefonu komórkowego w zakresie sposobów radzenia sobie ze stresem

\begin{tabular}{|c|c|c|c|c|c|c|}
\hline \multirow{2}{*}{ Skale KRS } & \multicolumn{2}{|c|}{ Kobiety zagrożone } & \multicolumn{2}{|c|}{ Kobiety niezagrożone } & \multirow{2}{*}{$\mathrm{t}$} & \multirow[b]{2}{*}{$\mathrm{p}$} \\
\hline & $\mathrm{M}$ & sd & $\mathrm{M}$ & sd & & \\
\hline Bagatelizacja & 11,42 & 3,73 & 11,71 & 3,47 & $-0,69$ & ni \\
\hline Porównywanie z innymi & 7,80 & 3,94 & 7,98 & 3,74 & $-0,41$ & ni \\
\hline Obrona przed winą & 9,78 & 2,82 & 8,97 & 2,96 & 2,36 & 0,019 \\
\hline Odwrócenie uwagi & 12,00 & 3,49 & 11,86 & 3,51 & 0,35 & ni \\
\hline Zastępcza satysfakcja & 12,18 & 3,93 & 10,60 & 4,36 & 3,18 & 0,002 \\
\hline Poszukiwanie samopotwierdzenia & 10,48 & 3,79 & 10,40 & 3,87 & 0,16 & $\mathrm{ni}$ \\
\hline Próba kontroli przebiegu sytuacji & 13,12 & 3,67 & 13,35 & 3,57 & $-0,54$ & ni \\
\hline Próba kontroli swoich reakcji & 13,14 & 3,55 & 13,43 & 3,02 & $-0,75$ & ni \\
\hline Pozytywne instruowanie siebie & 11,69 & 3,76 & 11,82 & 3,44 & $-0,30$ & ni \\
\hline Poszukiwanie społecznego wsparcia & 13,64 & 4,92 & 12,90 & 4,40 & 1,35 & ni \\
\hline Tendencja unikowa & 13,00 & 2,97 & 12,78 & 3,11 & 0,62 & ni \\
\hline Tendencja ucieczkowa & 12,13 & 4,48 & 9,66 & 4,10 & 4,93 & 0,001 \\
\hline Izolowanie się od ludzi & 9,14 & 4,34 & 6,90 & 4,41 & 4,32 & 0,001 \\
\hline Dalsze zajmowanie się w myślach & 15,55 & 4,83 & 13,33 & 5,01 & 3,81 & 0,001 \\
\hline Rezygnacja & 12,41 & 3,28 & 10,16 & 3,43 & 5,64 & 0,001 \\
\hline Użalanie się nad sobą & 11,96 & 3,85 & 9,54 & 4,09 & 5,12 & 0,001 \\
\hline Obwinianie siebie & 12,27 & 4,10 & 10,46 & 4,29 & 3,61 & 0,001 \\
\hline Agresja & 9,50 & 4,02 & 7,00 & 3,89 & 5,39 & 0,001 \\
\hline Uzależnienie & 2,75 & 2,91 & 2,20 & 2,71 & 1,67 & $\mathrm{ni}$ \\
\hline
\end{tabular}


Tab. 3. Porównanie mężczyzn zagrożonych i niezagrożonych uzależnieniem od telefonu komórkowego w zakresie sposobów radzenia sobie ze stresem

\begin{tabular}{|l|c|c|c|c|c|c|}
\hline \multirow{2}{*}{\multicolumn{1}{c|}{ Skale KRS }} & \multicolumn{2}{c|}{ Mężczyźni zagrożeni } & \multicolumn{2}{c|}{ Mężczyźni niezagrożeni } & \multirow{2}{*}{$\mathrm{t}$} & \multirow{2}{*}{$\mathrm{p}$} \\
\cline { 2 - 5 } & $\mathrm{M}$ & $\mathrm{sd}$ & $\mathrm{M}$ & $\mathrm{sd}$ & & \\
\hline Bagatelizacja & 11,97 & 3,40 & 11,11 & 3,49 & 1,20 & $\mathrm{ni}$ \\
\hline Porównywanie z innymi & 9,32 & 3,79 & 9,74 & 3,94 & $-0,53$ & $\mathrm{ni}$ \\
\hline Obrona przed winą & 9,95 & 3,03 & 8,95 & 3,09 & 1,57 & $\mathrm{ni}$ \\
\hline Odwrócenie uwagi & 11,45 & 3,04 & 10,85 & 3,61 & 0,85 & $\mathrm{ni}$ \\
\hline Zastępcza satysfakcja & 11,03 & 4,30 & 9,48 & 3,85 & 1,86 & $\mathrm{ni}$ \\
\hline Poszukiwanie samopotwierdzenia & 10,95 & 3,73 & 10,16 & 3,39 & 1,08 & $\mathrm{ni}$ \\
\hline Próba kontroli przebiegu sytuacji & 13,24 & 2,82 & 14,02 & 3,62 & $-1,13$ & $\mathrm{ni}$ \\
\hline Próba kontroli swoich reakcji & 13,55 & 3,69 & 12,98 & 3,39 & 0,79 & $\mathrm{ni}$ \\
\hline Pozytywne instruowanie siebie & 11,53 & 3,30 & 11,75 & 3,31 & $-0,33$ & $\mathrm{ni}$ \\
\hline Poszukiwanie społecznego wsparcia & 12,05 & 5,60 & 10,02 & 3,98 & 1,96 & 0,055 \\
\hline Tendencja unikowa & 12,50 & 2,65 & 12,25 & 3,35 & 0,40 & $\mathrm{ni}$ \\
\hline Tendencja ucieczkowa & 10,95 & 4,45 & 8,74 & 4,00 & 2,56 & 0,012 \\
\hline Izolowanie się od ludzi & 8,53 & 4,06 & 6,28 & 4,37 & 2,56 & 0,012 \\
\hline Dalsze zajmowanie się w myślach & 13,74 & 5,22 & 11,16 & 5,08 & 2,43 & 0,017 \\
\hline Rezygnacja & 10,68 & 3,77 & 9,18 & 3,62 & 1,98 & 0,051 \\
\hline Użalanie się nad sobą & 11,47 & 3,84 & 8,25 & 4,11 & 3,90 & 0,001 \\
\hline Obbwinianie siebie & 11,66 & 4,17 & 8,69 & 3,85 & 3,61 & 0,001 \\
\hline Agresja & 8,37 & 4,15 & 6,15 & 3,21 & 2,99 & 0,004 \\
\hline Uzależnienie & 3,58 & 3,80 & 1,77 & 2,68 & 2,56 & 0,013 \\
\hline
\end{tabular}

Studiujący mężczyźni, zagrożeni uzależnieniem od telefonu komórkowego istotnie częściej, w porównaniu z mężczyznami z grupy kontrolnej, obwiniają siebie za zaistniałą sytuację trudną, użalają się nad własnym losem, długotrwale koncentrują się na własnym cierpieniu, rezygnują z podejmowania wysiłku, aby rozwiązać zaistniały problem, co z kolei może być przyczyną utrzymującego się nastroju przygnębienia i beznadziejności. Mężczyźni zagrożeni uzależnieniem od telefonu komórkowego istotnie częściej w porównaniu do grupy mężczyzn niezagrożonych tym uzależnieniem mają trudności z podejmowaniem nowych, konstruktywnych działań, są zabsorbowani myślami na temat niedawno doświadczanych trudności oraz poszukują pomocy i wsparcia u innych.

Otrzymane wyniki wskazują również, że badani mężczyźni zagrożeni uzależnieniem od telefonu komórkowego częściej niż z grupy kontrolnej w obliczu stresu reagują agresją wobec siebie i innych, sięgają po alkohol i inne środki psychoaktywne, unikają kontaktu z ludźmi oraz planują i realizują zachowania mające na celu „ucieczkę" z doświadczanej sytuacji trudnej.

\section{Dyskusja wyników i wnioski}

Wyniki badań własnych informują, że studenci zagrożeni uzależnieniem od telefonu komórkowego w porównaniu z grupą niezagrożonych tym uzależnieniem znacząco częściej w sytuacji stresu wykorzystują emocjonalne i unikowe strategie radzenia sobie ze stresem, co oznacza, że częściej poszukują zastępczej satysfakcji, reagują rezygnacją, biernością, poczuciem przygnębienia i beznadziejności, obwi- niają siebie, użalają się nad sobą i poszukują wsparcia, długotrwale koncentrują się na doświadczanym cierpieniu, izolują się lub też reagują agresją i spożywają alkohol. Wyniki te są spójne ze zdaniem Robertsa i wsp. [43], którzy uważają, że korzystanie $\mathrm{z}$ telefonu komórkowego $\mathrm{w}$ sytuacji stresu może być traktowane jako stosowanie zastępczej satysfakcji lub też jako rodzaj uzależnienia. Ponadto badacze zwracają uwagę, że osoby z nasilonym neurotyzmem mogą używać telefonu komórkowego jako sposobu radzenia sobie ze stresem i niepokojem [44].

Niektórzy badacze tematu $[45,46,47]$ uważają, że nadmierne korzystanie z telefonu może być próbą ucieczki przed problemami, nieprzyjemnymi emocjami, a przyjemność doświadczana podczas korzystania z telefonu przyczynia się do wyuczenia trwałej strategii reagowania na stres. Zgodnie z założeniami teorii ucieczki, która jest używana do wyjaśniania kompulsywnego kupowania $[45,46,47]$, uzależnienie od swojego telefonu, podobnie jak od zakupów - traktowane jest jako „drugorzędne, wtórne uzależnienie”, co oznacza, że korzystanie z telefonu stanowi próbę ucieczki przed innym, ważniejszym problemem, nudą, niską samooceną, trudnościami w relacjach interpersonalnych itp.

Co więcej, problematyczne korzystanie $\mathrm{z}$ telefonu komórkowego, według Billieux i wsp. [48] jest podyktowane potrzebą zapewnienia sobie wsparcia ze strony otoczenia, a telefon komórkowy jest instrumentem, który ma pomóc w jej zaspokojeniu. Korzystanie z telefonu komórkowego i jego funkcji może być również traktowane jako sposób reagowania na stres, odwrócenia uwagi od problemów poprzez poszukiwanie zastępczej satysfakcji, szczególnie w związku z możliwościami jakie oferuje 
smartfon - korzystania z Internetu, grania w gry komputerowe, słuchania muzyki itp. [38]. Jednocześnie wielu badaczy $[49,50,51]$ zajmujących się problematyką uzależnienia od gier komputerowych i Internetu zwraca uwagę, że za nadmiernym graniem w gry mogą kryć się nieadaptacyjne sposoby radzenia sobie ze stresem. Wan i Chiou [52] wskazują, że gry mogą być traktowane przez graczy jako sposób emocjonalnego radzenia sobie poprzez ucieczkę od samotności, izolacji i nudy, a także jako forma relaksu czy rozładowywania złości i frustracji.

W związku z tym, że smartfon pozwala na nieograniczone korzystanie z Internetu, należy zwrócić uwagę na opinię Li i wsp. [53], którzy podkreślają, że osoby patologicznie korzystające z Internetu, częściej niż osoby niezagrożone tym uzależnieniem, w sytuacji stresu, obwiniają siebie za doznane niepowodzenia, uciekają od problemów, fantazjują o doznanych niepowodzeniach, stosują mechanizm racjonalizacji oraz nadużywają alkoholu i innych środków psychoaktywnych. Z drugiej strony Seepersad [54] uważa, że reagowanie na stres koncentracją na doznanych niepowodzeniach, współwystępuje $\mathrm{z}$ poszukiwaniem przez młodzież $\mathrm{w}$ sieci rozrywki, reagowanie zaś na sytuacje trudne ucieczką łączy się z częstym korzystaniem z internetowych komunikatorów oraz poczty internetowej, a poszukiwanie w sytuacji stresu zastępczej satysfakcji łączy się z częstym wysyłaniem e-maili [54].

W oparciu o uzyskane wyniki można przypuszczać, że konieczność sprostania wyzwaniom życia codziennego zwiększa poczucie zagubienia jednostki wywołując stres i negatywne emocje. Nieadaptacyjne sposoby radzenia sobie z sytuacją trudną potęgują odczuwany dyskomfort psychiczny i mogą sprzyjać wikłaniu się w różnego rodzaju problematyczne zachowania, w tym również zwiększać ryzyko uzależnienia od telefonu komórkowego.

\section{Wnioski}

1. Osoby zagrożone uzależnieniem od telefonu komórkowego w porównaniu z grupą kontrolną znacząco częściej w sytuacji stresu: poszukują zastępczej satysfakcji, reagują rezygnacją, biernością, poczuciem przygnębienia i beznadziejności, obwiniają siebie, użalają się nad sobą i poszukują wsparcia, długotrwale koncentrują się na doświadczanym cierpieniu, izolują się lub też reagują agresją i spożywają alkohol.

\section{Conflict of interest}

The authors have declared no conflict of interest.

\section{References:}

1. Griffiths M.D. Technological addictions. Clin Psychol Forum, 1995; 76: 14-19.

2. Griffiths M.D. Does Internet and computer "addiction"exist? Some case study evidence. Cyberpsychol. Behav, 2000; 3(2): 211-218.
3. Griffiths M.D. A 'components' model of addiction within a biopsychosocial framework. J. Subst. Use, 2005; 10(4):191-197.

4. Toda M., Monden K., Kubo K., Morimoto K. Mobile phone dependence and health-related lifestyle of university students. Soc. Behav. Pers., 2006; 34(10): 1277-1284.

5. Yen C.F., Tang T.C., Yen J.Y., Lin H.C., Huang C.F., Liu S.C., et al. Symptoms of problematic cellular phone use, functional impairment and its association with depression among adolescents in Southern Taiwan. J. Adolesc., 2009; 32: 863-873.

6. Grant J., Potenza N.M., Weinstein A., Gorelick A.D. Introduction to behavioral addictions. Am. J. Drug Alcohol Abuse, 2010; 36(5): 233-241.

7. Park B.W., Lee K.C. The effect of users' characteristics and experiential factors on the compulsive usage of the smartphone. Ubiquitous Computing and Multimedia Applications, 2011; 151: 438-446

8. Smetaniuk P. A preliminary investigation into the prevalence and prediction of problematic cell phone use. J. Behav. Addict., 2014; 3(1): 41-53.

9. Chóliz M. Mobile phone addiction: a point of issue. Addiction, 2010; 105(2): 373-374.

10. American Psychiatric Association. Diagnostic and statistical manual of mental disorders (5th ed.). Arlington, VA: American Psychiatric Publishing; 2013.

11. Klasyfikacja zaburzeń psychicznych i zaburzeń zachowania w ICD-10. Badawcze kryteria diagnostyczne. Kraków, Warszawa; Uniwersyteckie Wydawnictwo Medyczne „Vesalius”. Instytut Psychiatrii i Neurologii: 2000.

12. Bianchi A, Phillips J.G. Psychological predictors of problem mobile phone use. Cyberpsychol. Behav, 2005; 8(1): 39-51.

13. Billieux J., Van der Linden M., D'Acremont M., Ceschi G., Zermatten A. Does Impulsivity Relate to Perceived Dependence on and Actual Use of the Mobile Phone? Appl. Cogn. Psychol, 2007; 21(4): 527-537.

14. Billieux J. Problematic use of the mobile phone: A literature review and a pathways model. Curr. Psychiatry Rev., 2012; 8: 299-307.

15. López-Fernández O., Honrubia-Serrano L., Freixa-Blanxart M., Gibson W. Prevalence of Problematic Mobile Phone Use in British Adolescents. Cyberpsychol. Behav. Soc. Netw., 2013; 17(2): 91-98.

16. Hong F.Y., Chiu S.I., Hong D.H. A model of the relationship between psychological characteristics, mobile phone addiction and use of mobile phones by Taiwanese university female students. Comput. Human Behav., 2012; 28(6): 2152-2159.

17. Leung L. Leisure boredom, sensation seeking, self-esteem, addiction symptoms and patterns of mobile phone use. In: E. Korini, S. Utz, M. Tanis, S. Barnes, eds., Mediated interpersonal communication New York; Routledge: 2008, pp. 359-381.

18. Leung L. Linking psychological attributes to addiction and improper use of the mobile phone among adolescents in Hong Kong. J. Child. Media, 2008; 2(2): 93-113.

19. Potembska E., Pawłowska B. Właściwości psychometryczne Kwestionariusza do Badania Uzależnienia od Telefonu Komórkowego (KBUTK). Bad. Schizofr., 2009; 10: 322-329.

20. Fargues M., Lusar A., Jordania C. Sánchez X. Validación de dos es calas breves para evaluar la adicción a Internet y el abuso del móvil. Psicothema, 2009; 21(3): 480-485.

21. Pedrero Pérez E.J., Rodríguez Monje M.T., Ruiz Sánchez De León J.M. Mobile phone abuse or addiction. A review of the literature. Adicciones, 2012; 24(2): 139-152.

22. Jenaro, C., Flores N., Gómez-Vela M., González-Gil F., Caballo C. Problematic internet and cell-phone use: Psychological, behavioral, and health correlates. Addict. Res. Theory, 2007; 15(3): 309-320. 
23. Toda M., Monden K., Kubo K., Morimoto K. Cellular phone dependence tendency of female university students. Jap. J. Hygiene, 2004; 59: 383-386.

24. Walsh S.P., White K.M., Young R.M. Needing to connect: the effect of self and others on young people's involvement with their mobile phones. Aust. J. Psychol., 2010; 62(4): 194-203.

25. Walsh S.P., White K.M., Young R.M. Over-connected? A qualitative exploration of the relationship between Australian youth and their mobile phones. J. Adolesc., 2008; 31(1): 77-92.

26. Mok J.Y., Choi S.W., Kim D.J., Choi J.S., Lee J., Ahn H., et al. Latent class analysis on internet and smartphone addiction in college students. Neuropsychiatr. Dis. Treat., 2014; 10: 817-828.

27. Billieux J., Van der Linden M., Rochat L. The role of impulsivity in actual and problematic use of the mobile phone. J. Appl. Psychol., 2008: 22(9): 1195-1210.

28. Billieux J, Gay P, Rochat L, Van der Linden M. The role of urgency and its underlying psychological mechanisms in problematic behaviours. Behav. Res. Ther., 2010; 48(11): 1085-1096.

29. Kim D., Lee Y., Lee J., Nam J.K., Chung Y. Development of Korean smartphone addiction proneness scale for youth. PLoS ONE, 2014; 9(5): e97920.

30. Lin Y.H., Chang L.R., Lee Y.H., Tseng H.W., Kuo T.B., Chen S.H. Development and validation of the smartphone addiction inventory(SPAI). PLoS ONE, 2014; 9(6): e98312.

31. White M.P., Eiser J.R., Harris P.R. Risk perceptions of mobile phone use while driving. Risk Anal., 2004; 24(2): 323-334.

32. Thomée S., Härenstam A., Hagberg M. Mobile phone use and stress, sleep disturbances, and symptoms of depression among young adults - a prospective cohort study. BMC Public Health, 2011; 11: 66.

33. Roberts J.A., Pirog S.F. A preliminary investigation of materialism and impulsiveness as predictors of technological addictions among young adults. Journal of Behavioral Addictions, 2013; 2(1): 56-62.

34. King A.L.S., Valença A.M., Silva A.C.O., Baczynski T., Carvalho M.R., Nardi A.E. Nomophobia: dependency on virtual environments or social phobia? Comput. Human Behav., 2013; 29(1): 140-144.

35. Billieux J., Philippot P., Schmid C., Maurage P, De Mol J., Van der Linden M. Is Dysfunctional Use of the Mobile Phone a Behavioural Addiction? Confronting Symptom-Based Versus Process-Based Approaches. Clin. Psychol. Psychother., 2014; 22(5): 460-468.

36. Shambare R., Rugimbana R. Zhowa T. Are mobile phones the 21st century addiction? Afr. J. Busin. Manag., 2012; 62(2): 573-577.

37. CBOS 2015. Korzystanie z telefonów komórkowych. Komunikat z badań nr 125/2015. Warszawa: Fundacja Centrum Badania Opinii Społecznej. www.cbos.pl/SPISKOM.POL /2015/K_125_15.PDF (dostęp 29.07.2016)

38. Roberts J.A., YaYa L.H. P., Manolis C. The invisible addiction: Cell-phone activities and addiction among male and female college students. J. Behav. Addict., 2014; 3(4): 254-265.

39. Potembska E. Uzależnienie i zagrożenie uzależnieniem od Internetu u młodzieży. Niepublikowana rozprawa doktorska. Lublin; Uniwersytet Medyczny: 2011.

40. Pawłowska B, Potembska E. Objawy zagrożenia i uzależnienia od telefonu komórkowego mierzonego Kwestionariuszem do Badania Uzależnienia od Telefonu Komórkowego, autorstwa Potembskiej i Pawłowskiej u młodzieży w wieku do 13 do 24 lat. Curr. Probl. Psychiatry, 2011; 12(4): 395-397.

41. Januszewska E. Style reagowania na stres w kontekście postaw rodzicielskich. Badania młodzieży w okresie adolescencji. In: D. Kornas-Biela ed., Rodzina: źródło życia i szkoła miłości. Lublin; Towarzystwo Naukowe KUL: 2000, pp. 313-344.

42. Januszewska E. Kwestionariusz radzenia sobie ze stresem (KRS). Wartość diagnostyczna i wyniki badań młodzieży. In: M.
Oleś ed., Wybrane zagadnienia z psychologii klinicznej i osobowości. Metody diagnostyczne w badaniach dzieci i młodzieży. Tom 6. Lublin; Towarzystwo Naukowe KUL: 2005, pp. 91-123.

43. Roberts J.A., Pullig Ch., Manolis Ch. I need my smartphone: A hierarchical model of personality and cell-phone addiction. Pers. Individ. Dif., 2015; 79: 13-19.

44. Amiel T., Sargent S.L. Individual differences in Internet usage motives. Comput. Human Behav., 2004; 20(6): 711-726.

45. Desarbo W., Edwards E. Typologies of compulsive buying behavior: A constrained clusterwise regression approach. J. Consum. Psychol., 1996; 5(3): 231-262.

46. Faber R.J., O'Guinn T.C. Compulsive buying. Review and reflection. In: C.P. Haugtvedt, P.M. Herr, F.R. Kardes eds., Handbook of Consumer Psychology. New York; Lawrence Erlbaum Associates: 2008, pp. 1039-1056.

47. Grover A., Kamins M. A., Martin I. M., Davis S., Haws K., Mirabito A. M., et al. From use to abuse: When everyday consumption behaviors morph into addictive consumptive behaviors. J. Res. Consumers, 2011; 19: 1-8.

48. Billieux J. , Maurage P., Lopez-Fernandez O. Kuss D.J., Griffiths M.D. Can Disordered Mobile Phone Use Be Considered a Behavioral Addiction? An update on current evidence and a comprehensive model for future research. Curr. Addict. Rep., 2015; 2(2): 156-162.

49. Young K.S. Addictive use of the Internet: A case study that breaks the stereotype. Psychol. Rep., 1996; 79: 899-902.

50. Grüsser S.M., Thalemann R., Albrecht U., Thalemann C.N. Exzessive Computernutzung im Kindesalter - Ergebnisse einer psychometrischen Erhebung. Wiener Klinische Wochenschrift, 2005; 117(5-6): 188-195.

51. Kwon J.H., Chung C.S., Lee J. The effects of escape from self and interpersonal relationship on the pathological use of internet games. Community Ment. Health J., 2011; 47(1): 113-121.

52. Wan C.S., Chiou W.B. Why are adolescents addicted to online gaming? An interview study in Taiwan. Cyberpsychol. Behav, 2006; 9(6): 762-766.

53. Li H., Wang J., Wang L. A Survey on the Generalized Problematic Internet Use in Chinese College Students and its Relations to Stressful Life Events and Coping Style. Int. J. Ment. Health Addict., 2009; 7(2): 333-346.

54. Seepersad S. Coping with Loneliness: Adolescent Online and Offline Behavior. Cyberpsychol. Behav, 2004; 7(1): 35-39.

\section{Correspondence address}

Beata Pawłowska

Department of Psychiatry and Psychiatric Rehabilitation of Medical University of Lublin, Poland 20-439 Lublin, ul. Głuska 1 Phone: 817440967

e-mail: pawlowskabeata@tlen.pl

Otrzymano: 06.09.2016

Zrecenzowano: 10.10.2016, 14.10.2016

Przyjęto do druku: 23.10.2016 